\title{
Effect of Inflation on Economic Growth of Ethiopia
}

\author{
Tizita Gebeyehu Yismaw
}

Department of Economics, Debre Brehan University, Debre Brehan, Ethiopia

\section{Email address:}

tizitageb12@gmail.com

\section{To cite this article:}

Tizita Gebeyehu Yismaw. Effect of Inflation on Economic Growth of Ethiopia. Journal of Investment and Management. Vol. 8, No. 2, 2019, pp. 48-52. doi: 10.11648/j.jim.20190802.13

Received: March 22, 2019; Accepted: April 26, 2019; Published: May 15, 2019

\begin{abstract}
The interaction between growth and inflation is one of the macroeconomic problems. Determining the effect of inflation on the economic growth of one country must be considered as a prior issue to build up a healthy economy. The main objective of this paper is to test that, whether inflation is an indicator or obstacle for economic growth of Ethiopia. Pair wise Granger causality test has been made to verify the objective of the paper and the pairwise Granger causality test result suggesting the existence of strong and significant correlation between variables pairwise. The test reveals a uni- directional causation between, real GDP and export (EX) and between real GDP and inflation and real GDP and investment. The causation runs from real GDP to inflation, real GDP to export and real GDP and investment respectively. In addition, taking the main objective which hypothesizes to proof whether inflation cause economic growth or the reverse holds true, the granger causality test pertains a uni- directional causation which runs from economic growth to inflation. Accordingly one can conclude that economic growth can cause for inflation but inflation doesn't cause economic growth during the study period in Ethiopia (1975-2016). Based up on the finding it is evident that balancing economic growth target in line with a monetary policy target may have a vital role to boost economic growth and control the level of inflation.
\end{abstract}

Keywords: Inflation, Economic Growth, Ethiopia, Johansen Co-Integration and Granger Causality

\section{Introduction}

The most important approach that claims the existence of a positive relationship between inflation and the growth is the Phillips Curve approach. This approach assumes that the high inflation causes low rates of unemployment therefore affects growth positively [1]. The empirical studies made afterwards showed that the relationship between inflation and the unemployment rate is valid in the short-term in case of unanticipated inflation. According to another approach, rising inflation results in contraction of the individual's wealth. In this context, individuals increase their savings to reach their pre-inflation wealth level and therefore interest rates fall with rising investments [2].

Annual average national head line inflation at the End of fiscal year $2013 / 14$ was $8.1 \%$, about 5.4 percentage points lower than the year 2012/2013. This was due to the slowdown in both food \&nonalcoholic beverages and nonfood inflation by 6.7 and 3.9 percentage points, respectively. As usual, food \& non-alcoholic beverage inflation contributed the lion's share to the 5.4 percentage point slowdown in annualized headline inflation [3].

As far the Economic Growth of Ethiopian economy is concerned it continued to register remarkable growth, and the Real GDP expanded by $10.3 \%$ in $2013 / 14$, which was beyond the GTP ${ }^{1}$ target of the country's economic growth rate which was $11.2 \%$ for $2013 / 14$. This economic growth has also been impressive compared with the $5.4 \%$ growth estimated for Sub-Saharan African countries in 2014 [4].

The idea of whether inflation can be an indicator or obstacle for economic growth is contradictory. Some economists argue that inflation can be the indicator of economic growth through encouraging investment in nonmonetary capital project this directly mean that inflation encourage people became concern central bank can adjust real interest rate and this lead to encourage investment in nonmonetary. While others believe that inflation cannot be indicator of economic growth rather it could be the obstacle

1 Growth and transformation Plan 
of economic growth there by increasing the opportunity cost of holding money and this is lead to uncertainty over future inflation which discourage both investment saving and likely economic growth [5].

Previous studies [6] conducted a study on the relationship between inflation and economic growth in Ethiopia by using quarterly based data and, he found that there exists a positive long-run relationship between inflation and economic growth. And [7] conducted the study on the adverse effect of inflation in fixed income earner and she concluded that, inflation adversely affects fixed income earner but the effect of inflation is not bounded on fixed income earner. Rather inflation is always and an everywhere phenomena, that All firm, businessmen, consumer and every society affected by the adverse effect of inflation.

Accordingly the main focus of this study is to see the overall relationship between inflation and economic growth and other factors which determine economic growth in Ethiopia. By employing 42 year time series data and using econometric analysis. What distinguishes this study from previous researchers is that, the present study investigates the current trend of variables included under the model there by take account of recent data. Therefore, this paper is also significant by filling the time gap using data's ranging from the year 1975-2016. As a result, the study is motivated by the basic questions raised in the following section to partially fill in the existing literature, time and variable gap by examining the effect of inflation on economic growth from the context of Ethiopia. Therefore, the paper comes up with a conclusion on the contradictory idea of "whether inflation is an indicator or obstacle for economic growth" in Ethiopian economic context with methodology at hand.

The general objective of the study is to examine the effect of inflation on economic growth of Ethiopia. In addition, the Specific objectives are to:

Determine the long run relationship between inflation and economic growth in Ethiopia

Examine the causation of direction between inflation and economic growth in Ethiopia

Determine the effect of investment and export on economic growth of Ethiopia

Since the major objective of this paper is to test specific relationships among the four Macroeconomic variables under study, namely: real GDP, Inflation, export and investment. Accordingly the paper sets hypotheses as follows:

Does Real GDP growth causes inflation to change or inflation cause RGDP for the Ethiopian economy?

Does investment causes the Real GDP or Real GDP causes investment for the Ethiopian economy?

Does export growth causes the Real GDP to change or Real GDP causes export for the Ethiopian economy?

The remaining part of the paper is organized as follows: The next section looks into methodological issues. The third section provides discussion of results and the final section deals with brief concluding remarks.

\section{Methodology of the Study}

\subsection{Source and Type of Data}

The data which used in this study is collected from National Bank of Ethiopia (2016). The data are annual time series data reflecting to annual inflation rate (CPI), Gross domestic product (RGDP), export (EX) and the domestic investment (INT). The data covered the period of $1975-$ 2016.

\subsection{Model Specification}

After the data is collected and coded both descriptive and econometric method of data analysis is employed. Descriptive method of data analysis is used to explain the frequency and descriptive statistics of data and Time series econometrics method of data analysis is employed to explain the inferential relationship between Real GDP, inflation (CPI) export (EX) and investment (INT). Granger Causality test is used to explore the short-run direction of causality between GDP, EX and CPI, and co-integration analysis is employed to investigate the existence of long-run relationship.

Using the literatures on the effect of inflation on economic growth and following the works of previous researchers such as [8] and [6] the model employed in this study is expressed in the following manner:

$$
\mathrm{RGDP}=\mathrm{f}(\mathrm{CPI}, \mathrm{EX}, \mathrm{INT})
$$

In linear form the model written as:

$$
\operatorname{RGD}_{\mathrm{t}}=\beta_{0}+\beta_{1} \sum_{\mathrm{t}=1}^{\mathrm{n}} \mathrm{CPI}_{\mathrm{t}}+\beta_{2} \sum_{\mathrm{t}=1}^{\mathrm{n}} \mathrm{EX}_{\mathrm{t}}+\beta_{3} \sum_{\mathrm{t}=1}^{\mathrm{n}} \mathrm{INT}_{\mathrm{t}}+\mu \mathrm{i}
$$

Where, $\beta_{1}<0, \beta 2>0, \beta 3>0$

Where: $\mathrm{CPI}=$ inflation

$\mathrm{EX}=$ export

$\mathrm{INT}=$ investment

$\mathrm{T}=$ time

Variable descriptions

Economic growth; Economic growth is the increase in the market value of the goods and services produced by an economy over time. And it is affected by the inflation, investment and export.

Inflation; Inflation is a sustained increase in the general price level of goods and services in an economy over a period of time and it affects economic growth either positively, negatively or both

Investment; means expenditure of capital in cash or in kind or in both by an investor to establish a new enterprise or to expand or upgrade one that already exists; and is expected to have positive impact to real GDP.

Export: means shipping the goods and services out of the port of a country. The seller of such goods and services is referred to as an "exporter" and is based in the country of export whereas the overseas based buyer is referred to as an "importer". And export expected to be positively related to economic growth.

Residual (Ui): it explains the unexplained part of the model or the variable not included in the model included 
under the error term.

\section{Results and Discussion}

\subsection{Correlation}

Table 1. Correlation between Real GDP, CPI and EX, INT 1975-2016 in Ethiopian economy.

\begin{tabular}{lllll}
\hline Variables & RGDP & CPI & EX & INT \\
\hline RGDP & 1.000000 & 0.449747 & 0.926737 & 0.953692 \\
CPI & 0.449747 & 1.000000 & 0.407759 & 0.439941 \\
EX & 0.926737 & 0.407759 & 1.000000 & 0.987340 \\
INT & 0.953692 & 0.439941 & 0.987340 & 1.000000 \\
\hline
\end{tabular}

Table 1, shows the two way correlation between real GDP, CPI and EX. It proofs the existence of high two ways correlation between variables used under the study. The highest correlation happens between Export (EX) and investment (INT), with the magnitude of the correlation is (0.987) and Investment is correlated with Real GDP with a magnitude of (0.95). The magnitude of correlation between export (EX) and Real GDP is found to be significant (0.926). On the other hand there exist low correlation between inflation and export, investment and inflation and between real GDP and inflation.

\subsection{Result of Test of Stationarity}

Testing for the existence of unit roots is of major interest in the study of time series Models and co-integration. In this study, the Augmented Dickey Fuller (ADF) test is employed to test the stationary of the variables and the test result is given in Table 2 .

Table 2. Unit root test (ADF2) test results.

\begin{tabular}{llll}
\hline Variable & $\begin{array}{l}\text { ADF Test } \\
\text { Statistic }\end{array}$ & $\begin{array}{l}\text { Critical } \\
\text { Value }\end{array}$ & Order of Integration \\
\hline RGDP & -5.197052 & -3.610453 & $\mathrm{I}(1)$ \\
CPI & -2.847738 & -2.606857 & $\mathrm{I}(1)^{*}$ \\
EX & -4.390098 & -3.610453 & $\mathrm{I}(1)$ \\
INT & -2.753151 & -2.607932 & $\mathrm{I}(1)^{*}$ \\
Residual & -6.034188 & -3.632900 & $\mathrm{I}(0)^{* * *}$ \\
\hline
\end{tabular}

$*, * *$ and $* * *$ shows $10 \%, 5 \%$ and $1 \%$ level of significance respectively; the null hypothesis is that there is a unit root.

Source: Eviews version 6 outputs

The test has shown that all variables are non-stationary in level (and they become stationary at first difference). Thus we can conclude that all variables included in the growth model are I (1). Hence, it is possible to employ Johansen procedure to test co integration.

The result of the ADF stationary tests for the residuals indicates that the residual is stationary at $1 \%$ level of significance (i.e. I (0)) showing that there is a long run relationship between the explanatory variables and growth. In other words, the linear combination of the variables of the model is stationary and they are co-integrated.

\subsection{Johansen co Integration Test Result}

Table 3. Johansen co integration test result.

Unrestricted Cointegration Rank Test (Trace)

\begin{tabular}{lllll}
\hline Hypothesized & & Trace & $\mathbf{0 . 0 5}$ & \\
\hline No. of CE(s) & Eigenvalue & Statistic & Critical Value & Prob.** \\
None * & 0.573041 & 61.25071 & $47.85613^{*}$ & 0.0017 \\
At most 1 & 0.381376 & 29.76125 & 29.79707 & 0.0505 \\
At most 2 & 0.251945 & 11.99170 & 15.49471 & 0.1573 \\
At most 3 & 0.033255 & 1.251369 & 3.841466 & 0.2633 \\
\hline
\end{tabular}

Trace test indicates 1 cointegrating eqn(s) at the 0.05 level

$*$ denotes rejection of the hypothesis at the 0.05 level

Table 3 clearly shows that the null hypothesis of no cointegration is rejected by both the $\lambda \max$ and the $\lambda$ trace statistics. So it is used only one co integrating vector that relates economic growth which is the dependent variable to CPI, EX and INT.

\subsection{The Long Run Equation}

The result of Johansen co integration provided in the table 3 indicates the existence of long run equilibrium relationship among the variables in model.

Table 4. Estimates of $\beta$ coefficients normalized to RGDP.

\begin{tabular}{lllll}
\hline Variables & RGDP & CPI & EX & INT \\
\hline $\mathrm{B}$ & 1 & -271.27 & 0.005 & -6.83 \\
\hline
\end{tabular}

Note: since the table is not in the equation form the real sign of coefficients are changed.

Finally, the structural long run relationship derived from the co-integrating vector normalized with respect to RGDP can be represented as:

$$
\mathrm{RGDP}=\begin{gathered}
271.27 \mathrm{CPI} \\
(0.701)
\end{gathered}-\begin{gathered}
0.05 \mathrm{EX} \\
(0.070 *)
\end{gathered}+\begin{gathered}
6.83 \mathrm{INT} \\
(0.000 * *)
\end{gathered}-\begin{gathered}
12.15 \\
(0.000 * *
\end{gathered}
$$

The long run equation suggested that investment positively affects economic growth of Ethiopia in the long run. Whereas export has negative influence on economic growth of Ethiopia in the long run. The results are statistically significant for all variables except for inflation. The long run effect of inflation on economic growth is statistically insignificant. This shows that inflation has no long run effect on economic growth of Ethiopia.

A 1 unit increase in investment will promote economic growth of Ethiopia by 6.83 units. The unexpected result is found on the relationship of export and growth. A 1 unit increase in export decreases growth by 271.27 units. This result is not expected and it is may be due to the export of agricultural products by Ethiopia in which the price of those agricultural products are the cheapest in the international market and it may not be able to promote economic growth. 


\subsection{Vector Error Correction Model (Short Run Equation)}

Table 5. The result of Short run model.

\begin{tabular}{|c|c|c|c|c|}
\hline Variable & Coefficient & Std. error & t- statistic & Prob. \\
\hline DCPI & -0.2745 & 0.164818 & 1.237741 & 0.31193 \\
\hline DEX & 47.79 & 0.204002 & 0.164818 & 0.733308 \\
\hline DINT & 0.094 & 0.610239 & -4.353034 & $0.02713 * *$ \\
\hline $\mathrm{C}$ & 0.182390 & 0.061803 & 2.951156 & $0.0058^{* * *}$ \\
\hline $\operatorname{ECM}(-1)$ & -0.276206 & 0.058386 & -2.586447 & $0.05732 * *$ \\
\hline R-squared & 0.815333 & \multicolumn{2}{|c|}{ Mean dependent variable } & 0.036250 \\
\hline Adjusted R- squared & 0.734080 & \multicolumn{2}{|c|}{ S.D dependent variable } & 0.564849 \\
\hline S. E of regression & 0.148431 & \multicolumn{2}{|c|}{ Akaike information criterion } & -0.819767 \\
\hline Sum squared resid & 0.727047 & \multicolumn{2}{|c|}{ Schwarz criterion } & -0.524213 \\
\hline Log likelihood & 23.39534 & \multicolumn{2}{|c|}{ F-statistic } & 88.63049 \\
\hline Durbin - Watson test & 1.99 & \multicolumn{2}{|c|}{ Prob (F- statistic) } & $0.000000 * * *$ \\
\hline
\end{tabular}

Source: Eviews version 6 output Note: ${ }^{* * *},{ }^{* *}$ and shows significance level at $1 \%$ and $5 \%$ level respectively

Table 5 indicates that only investment has positive and significant effect in the short run. A one unit increase in the investment increases growth by 0.09 units in the short run.

The result shows that the coefficient of the error-term (or the Speed of adjustment term) for the estimated equation is statistically significant and negative as expected. Thus, it will rightly act to correct any deviations from long-run equilibrium. The Coefficient -0.276206 shows that 27.62 percentage points' adjustments takes place each year towards long run equilibrium.

\subsection{Pair Wise Causality Result}

Table 6. Pair Wise Granger Causality Test Result.

\begin{tabular}{|c|c|c|c|c|c|}
\hline Pair wise hypothesis & Obs. & F-Statistic & p-value & Decision & Type for causality \\
\hline CPI does not Granger Cause RGDP & 42 & 1.55410 & 0.2265 & Accept H0: & No causality \\
\hline RGDP does not Granger Cause CPI & 42 & 2.14386 & 0.1332 & Reject H0: & Uni-directional causality \\
\hline EX does not Granger Cause RGDP & 42 & 0.76262 & 0.4745 & Accept H0: & No causality \\
\hline RGDP does not Granger Cause EX & 42 & 8.05164 & 0.0006 & Reject H0: & Uni-directional causality \\
\hline INT does not Granger Cause RGDP & 42 & 1.22957 & 0.3055 & Accept H0: & No causality \\
\hline RGDP does not Granger Cause INT & 42 & 9.24935 & 0.0006 & Reject H0: & Uni-directional causality \\
\hline EX does not Granger Cause CPI & 42 & 2.68949 & 0.0828 & Accept H0: & No causality \\
\hline INT does not Granger Cause CPI & 42 & 3.69325 & 0.0357 & Reject H0: & Uni-directional causality \\
\hline CPI does not Granger Cause INT & 42 & 4.96286 & 0.0131 & Reject H0: & Uni-directional causality \\
\hline INTdoes not Granger Cause EX & 42 & 2.47055 & 0.1000 & Accept H0: & No causality \\
\hline EX does not Granger Cause INT & 42 & 0.66484 & 0.5211 & Accept H0: & No causality \\
\hline
\end{tabular}

As it is observed from table 6, The Granger Causality test revealed the existence of a uni-directional causation between real GDP (RGDP) and Price level (CPI) in Ethiopia for the year 1975-2016. The direction of causation runs from real GDP to CPI. On the other hand, the reverse causation from export to real GDP not holds true. The causality relationship between real GDP and export were found to a uni-directional causation from real GDP to export (EX), suggesting that real income Granger causes export during 1975 to 2016 in Ethiopian economy. But no reverse causation found, from export (EX) to real GDP. And also there exists a unidirectional causation real GDP to Investment (INT), suggesting that a growth in gross domestic product Granger causes investment level during the study period in Ethiopian economy.

\section{Conclusion and Policy Implication}

Since the assumption of stationary is essential for time series variables, Unit root test (ADF) is carried out to avoid spurious regression and to enable for undertaking Granger Causality. The ADF result reveals that all variables became stationary in their level and first difference. And cointegration analysis has been utilized to analyze the association between variables under used the study. The results from correlation analysis prevails the existence of strong and significant correlation between the three variable $s$ pairwise. The Granger causality test reveals a uni- directional causation between, real GDP and export (EX) and between real GDP and inflation. The causation runs from real GDP to inflation and real GDP to export respectively.

From the causality relationship results obtained between real GDP and inflation regarded that that economic growth causes inflation and the reverse causation not holds true in Ethiopian economy. From the beginning the main objective of the study is to proof whether there exists uni- directional or bi-directional causation between real GDP growth and inflation rate in Ethiopia, accordingly the researcher obtained a conclusion which pertains economic growth can cause for inflation but inflation doesn't cause economic growth during 
the study period in Ethiopia since 1975-2016.

From the causation it is believed that inflation in Ethiopia is not solely determined by targeting monetary expansion rather economic growth has its own effect on the level of inflation. And production sector born inflation occurred in Ethiopia during the study period.

Accordingly it's recommended that balancing economic growth target in line with a monetary policy target may have a vital role to boost economic growth and control the level of inflation. For detail analysis further research should be made to assess the impact of monetary expansion on the level of inflation and economic growth more there by taking additional macro variables.

\section{References}

[1] Emrta, A. (2013), Inflation and Economic Growth: An Estimate of the Threshold Level of Inflation for Ethiopia, Addis Ababa, Ethiopia: Ethiopian Economic Association (EEA).

[2] Tamerat Kahssay (2017), Determinants of inflation in Ethiopia, journal of economics and sustainable development, vol 8 , no. 19 .

[3] Annual Report: National Bank of Ethiopia Annual Report, Fiscal year 2013-2016.

[4] Ashagrie Demile (2015), Inflation - Growth Nexus in Ethiopia: Evidence from Threshold Auto Regressive Model, Journal of economics and international finance, Vol 5(6), pp. 248-257.

[5] MOFED (2015), Macro economic developments in Ethiopia, Addis Abeba, MOFED, annual report.

[6] Abis Getachew Makuria (2013), the relationship between inflation and economic growth in Ethiopia, the University of Sydney, Australia.
[7] Tzita Aberea (2010), Adverse effect of inflation rate in Ethiopia, unpublished MSc thesis (economic policy analysis), Addis Ababa university, Addis Ababa.

[8] Michael M. (2008), Determinants of Recent Inflation in Ethiopia. Munich Personal RePEc Archive.

[9] Verbeek, Marno (2004), A Guide to Modern Econometrics, $4^{\text {th }}$ ed. John Wiley \& Sons Ltd, Erasmus University Rotterdam.

[10] Tesema Aberu, Tewodros Ayalew and Tewodros Tefera (2010), Determinants of inflation rate in Ethiopia, unpublished MSc thesis (economic policy analysis), Addis Ababa university, Addis Ababa.

[11] The Federal Democratic Republic of Ethiopia, Growth and Transformation Plan (GTP1) 2010/11-2014/15, September 2010, Addis Ababa.

[12] Teshome A. (2011), Sources of Inflation and Economic Growth in Ethiopia, Ethiopia Civil Service University.

[13] Gujarati D. N, ( 2004), Basic Econometrics, $4^{\text {th }}$ ed. The McGraw-Hill, Inc., New York.

[14] Hodge (2005), Inflation and growth in South Africa, Journal of Socio Economics issues, Vol. 38, 764-778.

[15] Fekadu Dereje (2011), Relationship between Inflation and Economic Growth in Ethiopia: Empirical Analysis, Journal of Economics and Sustainable Development Vol. 3 (12).

[16] Barro (1996), determinants of economic growth: a crosscountry empirical study, national bureau of economic research Cambridge, MA 02138.

[17] Getachew W. (1996): Economic Analysis of inflation in the short run and long run perspectives (the case of Ethiopia), Vienna University of Natural Resource and Life sciences. 